\title{
SDGs (Sustainable Development Goals): Coastal Land Management in Overcoming Poverty and Environmental Sustainability
}

\author{
Diang Adistya \\ Business Administration Science \\ Lampung University \\ Lampung, Indonesia \\ diang.adistya@fisip.unila.ac.id
}

\author{
A. Efendi \\ Business Administration Science \\ Lampung University \\ Lampung, Indonesia \\ a.effendi@fisip.unila.ac.id
}

\author{
Maulana Agung \\ Business Administration Science \\ Lampung University \\ Lampung, Indonesia \\ maulana.agung@fisip.unila.ac.id
}

\begin{abstract}
This research was conducted during the COVID-19 pandemic. This research aims to provide solutions for coastal land management using the SDGs concept. The method used is qualitative descriptive. The SDGs indicators used are economic, consumption, and production as well as environmental health. The results obtained are that the community's economy is greatly helped by the existence of ecotourism and marine tourism, when viewed from production and consumption, it can be seen that good governance makes coastal locations mutually integrated and profitable between ecotourism, marine tourism, and shrimp ponds or milkfish ponds. Next is in terms of environmental health which is measured using special tools so that it is known that the condition of seawater around the coast is very good.
\end{abstract}

\section{Keywords-SDGs, Ecotourism, Shrimp Farms.}

\section{INTRODUCTION}

Indonesia is a country with a long coastal area. This research was conducted in 2021 during the COVID-19 pandemic. The location under study is in Katibung District, Tarahan Village. This location is an area that has a coastline. The potential exists in the village of Tarahan, making the coast a center of community economic activities. Vannamei shrimp is one of the shrimp that has economic value and is an alternative type of shrimp that can be cultivated in Indonesia. Shrimp is relatively easy to cultivate. This caused the people of Tarahan village to start cultivating the shrimp [1]. Ariawan (2005) stated that the advantages possessed by vaname shrimp compared to other shrimp are high appetite, more resistance to disease and the shrimp environment is not good, and has a fast market at the international level [2]. Bray et al (1994) say that white vaname shrimp have euryhaline properties [3], which can live in a low salinity environment with a salinity range of $0.5 \mathrm{ppt}$ to 40 ppt, and Wyban \& Sweny (1991) say that the optimal temperature required by white vaname shrimp is between $23-30^{\circ} \mathrm{C}$ [4].

The people of Tarahan village are aware of the importance of maintaining natural conditions so that it has a good impact on life. The tourism in Tarahan village is in the form of mangrove forest tourism objects and also beach tourism. Tourism development based on environmental management is one means of education and character education. One of the tourism activities that many researchers pay attention to is the development of ecotourism (ecotourism) as a nature tourism activity based on environmental education. According to Nugroho (2015), the principle of ecotourism is to minimize impacts, foster environmental and cultural awareness, provide positive experiences for tourists (visitors) and recipients (hosts), provide benefits, and empower local communities [5]. The use of shrimp pond locations around the coast is certainly side by side with marine tourism and also ecotourism. With the concept of SDGs, it is hoped that certain conditions around the coast can be known so that they can improve the welfare of their communities sustainably.

\section{LITERATURE REVIEW}

\section{A. SDGs}

The Sustainable Development Goals are a new development agreement to replace the MDGs. The 2015-2030 validity period, agreed by more than 190 countries, contains 17 goals. In realizing sustainable ecological development, good environmental governance is needed, namely good governance in the management of environmental resources. Shaliza (2003) describes good environmental governance as the exercise of authority (politics, economy, and administration) capable of managing resources and national problems (public problems) effectively and efficiently, in response to community needs [6]. 


\section{B. Coastal land}

The potential of coastal land for the welfare of the community must be managed properly. The main things that become a part are the economy, consumption, and production as well as the health of the seawater. Research by Yusnikusuma et al (2016) states that the rapid development of ecotourism is not accompanied by efforts to control its development so that there is a lot of natural damage caused by tourism activities [7].

\section{Shrimp}

Purnamasari et al. (201) stated that vaname shrimp are native shrimp from Latin American waters with subtropical climatic conditions [8]. Vannamei shrimp is a type of shrimp that cannibals by eating each other if the feeding is late.

\section{RESEARCH METHODS}

This research was conducted in 2021, using a qualitative descriptive method which means describing a research subject. In this case, it is the SDGs for the use of coastal land for the community. The type of data used is qualitative data, namely primary and secondary data. The data collection procedure uses source triangulation. According to Sugiyono (2016: 241) means getting data from different sources with the same technique [9]. Informants in this study are people or actors who know and master the problem and are directly involved in the research problem. Qualitative research does not question the number of informants.

\section{A. Primary data}

Primary data is in the form of data sources that directly provide data to researchers or data obtained directly from the field.

\section{B. Secondary Data}

Secondary data is a data source that provides indirect data to data collectors (researchers), or data taken by researchers to support scientific research, such as using literature studies, books, journals, articles, and other sources.

\section{Data analysis method}

This study uses a qualitative descriptive data analysis method, namely by describing the use of coastal land and outlining the concept of SDGs which is currently being carried out by the government.

\section{RESULTS AND DISCUSSION}

Tarahan Village is a village located in South Lampung Regency, Katibung District. The access road adjacent to the provincial road makes the level of vehicle mobility very high. The total population of Taraahan village is 7,893 people. Tarahan villagers work in several sectors, both formal and informal, such as teachers, bank employees, company employees, farmers, and fishermen. With the village fund program by the government, Tarahan village has a BumDes that manages the potential of the existing village.

Marine tourism, mangrove ecotourism or milkfish, and shrimp farmers are the economic drivers of the Tarahan village community. This is supported by the existence of infrastructure in the form of access to tourist sites that are already very good in the form of road access that has been concreted. The people of Tarahan have the desire to work hard in advancing the village with Tarahan working since March 20, 2016.

The SDGs concept has a sustainable development goal for the welfare of its people by optimizing the existing potential but still paying attention to the preservation of the existing natural ecosystem. There are a total of 17 elements in the SDGs in general. In the tourism sector, there are three SDGs used.

\section{A. Economy}

The COVID-19 pandemic that has occurred since 2020 has prompted the government to issue several policies. In 2021, the policy used with the term work from home (BDR) makes most of the residents of Tarahan village work in the village for a lot of time. The potential for coastal land becomes very crowded in the late afternoon. This makes the economic cycle of the tourism sector increase.

TABLE I. DATA ON THE ABSORPTION OF NEW WORKERS 2019-2020

\begin{tabular}{|l|c|l|}
\hline Year & Labor & \multicolumn{1}{c|}{ Work } \\
\hline 2019 & 32 & Parking ticket, fisherman \\
\hline 2020 & 200 & Parking tickets, fishermen, traders \\
\hline 2021 & 233 & $\begin{array}{l}\text { Parking tickets, fishermen, traders, } \\
\text { shrimp ponds, milkfish ponds, catfish } \\
\text { ponds, clowns, music cafes, } \\
\text { photographers, cleaners }\end{array}$ \\
\hline
\end{tabular}

The development of coastal land from 2019-2021 in Tarahan village has an impact on the absorption of labor in several sectors. The high level of visits to tourist sites makes coastal areas vulnerable to contamination by waste generated from visitors. This of course must be given a solution so that tourist sites remain clean and also sustainable.

\section{B. Consumption and Production}

The location of coastal land is used as a location for shrimp ponds and milkfish ponds. At the shrimp pond location, 12 ponds have been produced, perkolam the amount of shrimp produced is 2.5 tons. The current price of shrimp is 85,000 per kilogram. Milkfish ponds can produce fish production for the consumption of the surrounding community and also tourist visitors. 
TABLE II. SHRIMP POND PRODUCTION 2019-2021

\begin{tabular}{|c|c|l|}
\hline Harvest & Pool & \multicolumn{1}{|c|}{ Production } \\
\hline 1 & 4 & 10 Ton \\
\hline 2 & 5 & 12 Ton \\
\hline 3 & 10 & 21 Ton \\
\hline 4 & 12 & Haven't harvested yet \\
\hline
\end{tabular}

With the existence of shrimp ponds around coastal tourist sites, the coastal land becomes productive. The results of shrimp ponds produced are quite good with a high shrimp survival rate and stable growth. This is because the layout of the pool is good.

Apart from the ponds and ponds sector, the surrounding community also produces processed food and drinks for marine tourism visitors and also mangrove forest ecotourism. In 2021 many tourists who visit want to enjoy young coconuts. Young coconuts are obtained from community plantations around the coast. Public consumption with tourism increases as a result of the high purchasing power of tourists who come to beach locations.

\section{Environment}

The existence of tourism activities, ecotourism, and also ponds around coastal lands must still pay attention to the health aspects of environmental conditions, especially water. By measuring the $\mathrm{pH}$ of seawater, it was found that the condition of seawater was very good.

TABLE III. MEASUREMENT OF PH

\begin{tabular}{|l|c|}
\hline Indicator & Measurement Results \\
\hline $\mathrm{pH}$ & 8.17 \\
\hline Salinitas & 35 \\
\hline
\end{tabular}

With the data obtained, it can be concluded that the existence of shrimp ponds on coastal land can still preserve the surrounding environment. These data illustrate that seawater is very good for the continuity of its habitat.

\section{REFERENCES}

[1] O. Amirna, R. Iba, and A. Rahman. Pemberian Silase Ikan Gabus pada Pakan Buatan bagi Pertumbuhan dan Kelangsungan Hidup Udang Vaname (Litopenaeus vannamei) pada Stadia Post Larva. Jurnal Mina laut Indonesia 1.01 (2013): 93-103.

[2] K. Ariawan. Penerapan Budidaya Udang Vaname Pola Semi Intensif di Tambak Laporan Tahunan Departemen Kelautan dan Perikanan. Jepara: Direjen Perikanan Budidaya. 2005.

[3] W. A. Bray, A. L. Lawrence, and J. R. Leung-Trujillo. The effect of salinity on growth and survival of Penaeus vannamei, with observations on the interaction of IHHN virus and salinity. Aquaculture 122.2-3 (1994): 133-146.

[4] J.W. Wyban and J. N. Sweeney. Intensive Shrimp Production Technology. The Oceanic Institute Shrimp Manual. Honolulu, Hawai, USA. 1991.

[5] I Nuoroho F.kowisata dan Pomhanounan Rerkelanjutan. Cetakan ke-2. Pustaka Pelajar. Yogyakarta. 2015.

[6] F. Shaliza. Pembangunan Sektor Perikanan dan Keberlanjutan Lingkungan Perairan: Kasus Masyarakat Nelayan di Desa Bulu, Kabupaten Jepara, Jawa Tengah". Disertasi. Program Studi Sosiologi Pedesaan. Program Pascasarjana. Institut Pertanian Bogor, Bogor. 2003. (unpublished).

[7] Yusnikusumah, T. Rizkiana, and E. Sulystiawati. "Evaluasi Pengelolaan Ekowisata di Kawasan Ekowisata Tangkahan Taman Nasional Gunung Leuser Sumatera Utara." Jurnal perencanaan wilayah dan kota 27.3 (2016): 173-189.

[8] I. Purnamasari, D. Purnama, and M. A. F. Utami. "Pertumbuhan udang vaname (litopenaeus vannamei) di tambak intensif." Jurnal Enggano 2.1 (2017): 58-67.

[9] Sugiyono. Metode penelitian kuantitatif,kualitatif dan R\&D.PT Alfabet. Bandung. 2016. p.241. 